\title{
Desain Analisis Semantik Alquran Model Ensiklopedik: Kritik atas Model Semantik Toshihiko Izutsu
}

\section{(The Qur'anic Semantic Analysis of Encyclopedic Model: Critics to Semantic Model of Toshihiko Izutsu)}

\author{
Dadang Darmawan ${ }^{1}$, Irma Riyani ${ }^{2}$, Yusep Mahmud Husaini ${ }^{3}$ \\ UIN Sunan Gunung Djati Bandung \\ 11dadangdarmawan@uinsgd.ac.id, 2irmariyani@uinsgd.ac.id, ${ }^{3 h}$ usaezn@gmail.com
}

DOI: $10.29240 /$ alquds.v4i2.1701

Submitted: 2019-06-19| Revised: 2020-09-03 |Accepted: 2020-09-22

\begin{abstract}
This research attempts to build a new model of semantic analysis to the Qur'anic text, which is called encyclopedic semantics. This research contributes to the improvement of Qur'anic semantic analysis of Izutsu and as an alternative model. This article employs a qualitative method and research and development (R \& D) with an analytical description of the data gathered. Analysis of the data consists of several steps, namely analyzing Izutsu's model of Qur'anic semantics, identifying and verifying several limitations on Izutsu's model, building a new design of Qur'anic semantics to perfection, and lastly, demonstrating the new model in the semantics applied to the Qur'anic text. This research shows that based on the laxity found in Izutsu's model, this research creates a new model of semantics analysis to the Qur'an called encyclopedic semantics as an alternative model to the existing model from Izutsu. The semantics model of encyclopedic perfects the Izutsu model with significant differences. The semantics model of encyclopedic aims at rendering the meanings of the Qur'an from global to particular. In contrast, the Izutsu model is to achieve meanings from particular to global. Besides, the encyclopedic model of semantics is part of mawdlu'iy (thematic) method of interpreting the Qur'an. This model gains its legitimation from Islamic tradition. The sample of this model is shown in the application of the Qur'anic word matar.
\end{abstract}

Keywords: Semantics; Izutsu, encyclopedic semantics, research design, Alquran, Mațar

\begin{abstract}
Abstrak. Penelitian ini bertujuan untuk merancang analisis semantik sebagai alternatif dari analisis ala Izutsu yang kemudian penulis namai semantik ensiklopedik. Metode yang digunakan dalam penelitian ini bersifat deskriptif analitis dan pengembangan ( $\& D)$. Untuk pengembangan design analisis semantik ensiklopedik ini dilakukan lima tahapan analisis. Pertama, observasi secara mendalam terhadap desain semantik Alquran model Izutsu. Kedua, mengidentifikasi kekurangan dari model tersebut. Ketiga, mendesain model yang baru. Keempat, menerapkan model baru tersebut secara ekperimental terhadap beberapa tema dalam Alquran. Kelima mengambil kesimpulan apakah model


baru itu layak digunakan atau tidak.Setelah dilakukan penelitian, diperoleh dua temuan. Pertama, semantik Alquran model Izutsu ternyata memiliki empat kekurangan terkait sifat, legitimasi, referensi, dan kegunaannya. Kedua, desain analisis semantik Alquran model ensiklopedik terbukti bisa diterapkan secara lebih baik dan dapat menutupi kekurangan semantik Alquran model Izutsu. Penerapan aplikasinya dapat dilihat dari contoh yang disajikan tentang makna kata Matar dalam Alquran.Model semantik ensiklopedik ini merupakan bagian dari tafsir mawdlu'iy sehingga mendapat legitimasinya dalam kajian studi Islam.

Keyword: Semantik Izutsu; semantik ensiklopedik; Desain Penelitian; Alquran; Mațar

\section{Pendahuluan}

Semantik adalah studi tentang makna. ${ }^{1}$ Sementara itu, semantik Alquran adalahsemantik yang digunakan sebagai alat bantu untuk memahami Alquran. Untuk kepeluan ini dibutuhkan beberapa penyesuaian supaya materi-materi dalam ilmu semantik dapat berguna. Penyesuaian-penyesuaian inilah yang akan menjadi ciri khas semantik Alquran.

Semantik Alquran mulai ramai diperbincangkan ketika Toshihiko Izutsu mempublikasikan bukunya yang berjudul Ethico-Religious Concepts in the Qur'an pada tahun 1966. Buku ini dipuji-puji sebagai studi terbaik tentang pandangandunia Alquran yang pernah ditulis dalam bahasa yang dapat dimengerti oleh dunia Barat. ${ }^{2}$ Buku Izutsu lainnya yang juga terkenal adalah God and Man in the Qur an: Semantics of the Qur anic Weltanschaunng yang dipublikasikan pertama kali tahun $1964 .{ }^{3}$ Begitu pentingnya kedua buku ini, sehingga telah menjadi semacam buku panduan bagi kajian semantik Alquran di masa selanjutnya.

Namun demikian, ada celah dalam desain analisis semantik Alquran yang ditawarkan oleh Izutsu. Sebagai seorang outsider, Izutsu telah mengembangkan penelitian semantik sesuai dengan kepentingannya. Ia ingin tahu apa inti ajaran Alquran. Baginya tujuan semantik Alquran adalah untuk memahami weltanschauung (pandangan dunia) Alquran secara keseluruhan. ${ }^{4}$ Untuk tujuan itu, ia mencoba meneliti konsep-konsep partikular Alquran untuk memperoleh pemahaman global mengenai inti gagasan Alquran. Adapun rancang bangun (model) penelitian semantik Alquran yang dia gunakan adalah sebagai berikut: (1) Mula-mula ia memilih beberapa kata yang dianggap sebagai kunci untuk memahami Alquran. (2) Dari kata-kata kunci itu ia memilih beberapa kata fokus yang dianggap lebih penting dan lebih tinggi stratanya. (3) Dari kata-kata fokus

${ }^{1}$ F.H. George, Semantic (London: The English University Press, 1964), 1.

${ }^{2}$ Toshihiko Izutsu, Ethico-Religious Concepts in TheQur' an (London-Montreal: McGillQueen's University Press, 2002), x.

${ }^{3}$ Toshihiko Izutsu, God and Man in the Qur'an Semantics of the Qur'anic Weltanschanung (Petaling Jaya: Islamic Book Trust, 2008).

${ }^{4}$ Ibid., 3. 
itu ia memilih satu kata sebagai kata fokus tertinggi yang dianggap sebagai sentral bagi semua konsep dalam Alquran. ${ }^{5}$

Bagi seorang insider yakni orang Islam yang telah memahami atau paling tidak telah lama mengenal weltanschaunng Alquran, maka tujuan penggunaan semantik Alquran bukan lagi untuk mengetahui apa inti ajaran Alquran (karena ini adalah sesuatu yang bersifat arbitrer), tapi yang terutama adalah untuk mengetahui konsep-konsep tertentu dalam Alquran secara lebih mendalam. Jika Izutsu memulai penelitiannya dari konsep-konsep menuju pemahaman global mengenai Alquran, maka rancang bangun yang akan dikembangkan oleh penelitian ini adalah kebalikannya. Dari pemahaman yang global mengenai Alquran, penelitian ini akan berupaya memperdalam konsep-konsep partikular dalam Alquran. Hal ini sejalan dengan saran Saussure bahwa untuk mengerti suatu bahasa hendaklah dimulai dari keseluruhan menuju yang partikular. ${ }^{6}$

Rancang bangun analisis semantik Alquran yang dikembangkan dalam penelitian ini berbeda dengan apa yang ditawarkan oleh Izutsu. Rancang bangun yang baru akan sangat bermanfaat sebagai alat bantu bagi metode tafsir maudhu'i yang terlanjur sudah sangat terkenal itu. Metode tafsir maudhu'i (tafsir tematik)saat ini sedang mengalami kemandegan. Metode tafsir maudhui kerap dikritik karena potensi kemelanturannya yang sangat besar karena tidak fokus ${ }^{78}$ dan seringkali memenggal ayat dari rangkaiannya, yang disebabkan minimnya alat analisis yang kuat dalam langkah-langkah penelitiannya. Desain analisis semantik Alquran yang digagas oleh penulisdalam tulisan ini akan menutup kekurangan tersebut dengan menyajikan model analisis yang baru, lebih operasional, lebih baku dan bersipat komplementer bagi metode tafsir mandhu'i.

Untuk sampai pada rancang bangun tersebut, penelitian ini menggunakan metode penelitian kualitatif dengan berusaha mendeskripsikan data dan menganalisisnya. Penelitian ini juga bersifat pengembangan (R \& D) karena berusaha untuk mengembangkan design analisis baru dari kajian semantik. Untuk pengembangan design analisis semantik ini dilakukan lima tahapan analisis. Pertama, observasi secara mendalam terhadap desain semantik

5Ibid., 17, 22, 24.

${ }^{6}$ Saussure Ferdinand de, Saussure's Third Course of Lectures on General Linguistics (19101911) (Pergamon Press, 1993).

7“M. Tulus Yamani, Memahami Al-Qur'an Dengan Metode Tafsir Maudhu'I, J-PAI, 1 (2)," 2015, 290.

${ }^{8}$ Aisyah Aisyah, "Signifikansi Tafsir Maudhu'i dalam Perkembangan Penafsiran Al-

Qur'an” 1, no. 1 (February 20, 2019): 33, http://journal.uinalauddin.ac.id/index.php/tafsere/article/view/7449. 
Alquran model Izutsu. Kedua, mengidentifikasi kekurangan dari model tersebut. Ketiga, mendesain model yang baru. Keempat, menerapkan model baru tersebut secara ekperimental terhadap beberapa tema dalam Alquran.Kelima mengambil kesimpulan apakah model baru itu layak digunakan atau tidak.

\section{Pembahasan}

\section{Kritik Atas Semantik Alquran Model Izutsu}

Semantik dan tafsir Alquran pada dasarnya adalah dua bidang ilmu yang berbeda. Tafsir Alquran sudah lahir lebih dari 1400 tahun yang lalu. ${ }^{9}$ Sedangkan semantik, sebagai sebuah disiplin keilmuan, baru muncul sekitar awal abad ke$19 .{ }^{10}$ Walaupun, secara aplikatif, analisis semantik ini sudah dilakukan sejak tafsir Alquran dilakukan walaupun belum sesistematis seperti sekarang ini. Sebagaimana dinyatakan oleh Setiawan bahwa Maqatil bin Sulayman sebagai mufassir yang pertama melakukannya. ${ }^{11}$

Studi interdisipliner yang mencoba menggabungkan kedua bidang ilmu ini bermula pada tahun 1950-an. Pada dekade itu Toshihiko Izutsu mulai menggunakan analisis semantik sebagai pendekatan dalam studi Alquran dan berhasil. ${ }^{12}$ Ia mempublikasikan hasil penelitiannya pada tahun 1959, dalam sebuah buku berjudul TheStructureof theEthical Term in the Qur'an. Saat itu ia masih mengajardi Universitas Keiko Jepang. Namun demikian kajian semantik baru benar-benar populer ketika ia memperbaharui karyanya itu dan kembali menerbitkannya pada tahun 1966 dalam buku berjudul Ethico-Religious Concepts in the Qur'an. Saat itu ia mengajar di McGill University, Kanada. Buku ini kemudian diterbitkan kembali pada tahun 2002 oleh McGill dan Queen's University, karena dianggap masih relevan dengan kebutuhan zaman.

Satu dekade kemudian, tepatnya sekitar tahun 1970-an, kajian semantik Alquran yang digagas oleh Izutsu ini telah menyebar dan diterima dengan baik di berbagai kawasan dunia Islam. Semantik Alquran mulai diajarkan sebagai mata kuliah pada program sarjana dan pasca sarjana di berbagai universitas Islam. Saat itu, semantik Alquran yang ditawarkan oleh Izutsu menjadi trend baru pengkajian Alquran di dunia Islam yang memang sedang mengalami kemandegan dalam bidang metodologi. Dalam kasus Turki misalnya, segera setelah buku Izutsu diterjemahkan ke dalam bahasa Turki, Ismail Albayrak

49.

${ }^{9}$ Nashruddin Baidan, Rekonstruksi Ilmu Tafsir (Jakarta: Dana Bhakti Prima Yasa, 2000),

${ }^{10}$ Stephen Ullmann, Semantic an Introduction to the Science of Meaning (Oxford: Basil Backwell, 1972), 5.

${ }^{11}$ M. Nur Kholis Setiawan, Al-Qur'an Kitab Sastra Terbesar (Yogyakarta: eLSAQ Press, 2005).

${ }^{12}$ Partin, "Semantics of the Qur`an: A Consideration of Izutsu's Studies."History of Religions” V.9 No.4 (1970): 358-362. 
melaporkan bahwa pada dekade tahun 1970-an hingga tahun 1980-an para sarjana Alquran di Turki telah menerima dan mengikuti begitu saja cara-cara yang ditempuh oleh Izutsu dalam studi Alquran. Albayrak bahkan mengeluhkan ketidak-kritisan para sarjana Turki saat itu terhadap gagasan-gagasan yang ditawarkan oleh Izutsu. Menurut Albayrak baru pada dekade tahun 1990-an, kritik-kritik yang berbobot terhadap gagasan Izutsu mulai bermunculan seiring dengan berkembangnya tradisi akademik yang lebih baik di Turki. ${ }^{13}$

Di dunia Arab, gagasan semantik Alquran mulai diapresiasi setelah bukubuku Izutsu mulai diterjemahkan pada tahun 2007. Para sarjana Arab menyayangkan keterlambatan penerjemahan buku-buku itu. Namun segera setelah terjemahan buku Izutsu tersebar luas, apresiasi positif bermunculan dari kalangan sarjana Arab. Ini hal yang luar biasa mengingat pada umumnya tulisan tentang Alquran yang ditulis oleh non muslim sering dicurigai. ${ }^{14}$ Satu ulasan lengkap mengenai pokok-pokok pikiran Izutsu dan aplikasinya bahkan telah ditulis oleh salah seorang sarjana Arab bernama Salah al-Din al-Zaral. ${ }^{15}$

Di Indonesia hal yang serupa juga terjadi. Segera setelah buku-buku Izutsu diterjemahkan pada dekade tahun 1990-an, gagasan Izutsu tersebar luas dan diterima dengan baik oleh para peneliti Alquran di Indonesia. Semantik Alquran mulai diajarkan sebagai mata kuliah pada program sarjana dan pasca sarjana di berbagai universitas Islam terkemuka. Para sarjana Alquran di Indonesia juga umumnya mengikuti begitu saja cara-cara yang ditempuh oleh Izutsu dalam studi Alquran. Berdasarkan penelusuran pada laman garuda.risetdikti.go.id tanggal 30-9-2018, ditemukan tidak kurang dari 15 artikel ilmiah telah dipublikasikan dalam beragam jurnal berdasarkan prinsip-prinsip yang telah digariskan oleh Izutsu. Hampir kebanyakan artikel tersebut berupa aplikasi model analisis semantik ala Izutsu ${ }^{16}$ dan kajian lainnya berkaitan dengan

${ }^{13}$ Ismail Albayrak, "The Reception of Toshihiko Izutsu's Quranic Studies in the Muslim World: With Special Reference to Turkish Qur`anic Scholarship," Jurnal of Quranic Studies V. 14 No.1 (2012): 73-106.

${ }^{14}$ Eisa al-Akub, "Izutsu's Study of the Quran from an Arab Perspektif," Jurnal of Quranic Studies V. 14 No.1 (2012): 107-30.

${ }^{15}$ Shalah al-Din Al-Zaral, "Applied Semantics and the Qur`an: Izutsu's Methodology as a Case Study," Jurnal of Quranic Studies V. 14 No.1 (2012): 173-200.

${ }^{16}$ Lilik Ummi Kaltsum, "Alquran Dan Epistemologi Pengetahuan: Makna Semantik Kata Ra'a, Naẓar Dan Bașar Dalam Alquran," Wawasan: Jurnal Ilmiah Agama Dan Sosial Budaya Vol. 3, No. 1 (2018): 33-47.;Zulfikar, "Makna Ūlū Al-Albāb Dalam Al-Qur'an: Analisis Semantik Toshihiko Izutsu," Jurnal Theologia Vol 29, No 1 (2018): 109-40.;Rahman, Miftahur, "Kata Al-Ikhlash Dalam Alquran: Kajian Semantik," Al Quds: Jurnal Ilmu Alquran Dan Hadis Vol. 2, No. 2 (2018). 
pengenalan teori analisis semantik Izutsu, hanya menyebutkan beberapa saja. ${ }^{17}$ Namun demikian, kritik-kritik yang berbobot dan substantif untuk menyempurnakan gagasan Izutsu belumlah muncul sebagaimana yang terjadi di Turki.

Sampai saat ini ada empat kritik terhadap gagasan semantik Alquran yang ditawarkan oleh Izutsu, yakni terkait sifat, legitimasi, referensi, dan kegunaannya. Para sarjana yang telah lama menggeluti kajian semantik Alquran mulai menemukan celah-celah kekurangan dalam rancang bangun penelitian semantik yang diperkenalkan oleh Izutsu. Menurut mereka semantik Alquran versi Izutsu bersifat terlalu menyederhanakan isi kandungan Alquran yang sebetulnya sangat rumit. Ia mengabaikan referensi yang bersumber dari hadits dan kitab-kitab tafsir bi al-ma'tsur padahal di situ terdapat perkataan para shahabat dan tabi'in. Ia juga terlalu bertumpu pada model penelitian strukturalis khas Barat dan mengabaikan model penelitian khas Islam yang selama ini digunakan untuk menafsir Alquran. Hasil penelitian semantik Alquran berdasarkan rancang bangun yang digagas oleh Izutsu juga dianggap kurang berguna. Informasi yang dihasilkan dianggap tidak sanggup mengungkap murad Allah (kehendak Allah) yang harus dilaksanakan oleh para pengkaji Alquran. ${ }^{18}$

Upaya-upaya untuk menyesuaikan antara gagasan Izutsu dengan gagasan-gagasan baru khas Islam pun dilakukan. Namun demikian, upaya-upaya tersebut hingga saat ini belum menghasilkan sesuatu yang diharapkan. Di antara penelitian yang pernah dilakukan dalam konteks ini adalah penelitian berjudul Kontribusi Analisis Semantik Bagi Metode Tafsir Tematik. ${ }^{19}$ Di era digital sekarang ini, memang kajian semantik menemukan arah baru yang dikaitkan dengan tool data mining dan data retrieval untuk mengeluarkan kosa kata yang akan dibahas. ${ }^{20}$ Tentu saja kajian ini perlu juga mendapat apresiasi karena dengannya dapat memudahkan pencarian kosa kata dalam Alquran. Akan tetapi kajian ini tetap memerlukan kajian analisis substantif seperti yang akan kami tawarkan dalam artikel ini. Gagasan yang diusung penelitian ini dapat memberikan kontribusi

${ }^{17}$ Nafiul Lubabdan Muhammad Dimyati, "Urgensi Pendekatan Semantik Dalam Tafsir (Studi Pemikiran Toshihiko Izutsu)," Hermeneutik: Jurnal Ilmu Al-Qur'an Dan Tafsir Vol. 11, No. 1 (2017): 97-108.;Muzaqqi, "Semantic Approaches In Islamic Studies: The Review of Toshihiko Izutsu's Thought," Pedagogik: Jurnal Pendidikan Vol. 4, No. 1 (2016): 45-53.; Abdul Kabir HussainSolihu, "Semantics of the Qur'anic Weltanschauung: A Critical Analysis of Toshihiko Izutsu's Works," American Journal of Islamic Social Sciences Vol. 26, No. 4 (2009): 1-23.

${ }^{18}$ Albayrak, "The Reception of Toshihiko Izutsu's Quranic Studies in the Muslim World: With Special Reference to Turkish Quranic Scholarship,” n.d.

${ }^{19}$ Radiana, Aan, "Kontribusi Analisis Semantik Bagi Metode Tafsir Tematik" (Skripsi, Institut Agama Islam Negeri Sunan Gunung Djati Bandung, 1994).

${ }^{20}$ Karim Ouda, Quran Analysis: A Semantic Search and Intelligence System for the Quran (UK: Leeds University, 2015).; Noorhan Abbas\&Eric Atwell. Annotating the Arabic Quran with semantic web content tags.WACL'2 Second Workshop on Arabic Corpus Linguistics Proceedings of WACL'2 Second Workshop on Arabic Corpus Linguistics, 2013. 
sebagai penyempurnaan dari teori semantik yang sudah digagas oleh Izutsu. Model analisis semantik yang akan kami tawarkan berupaya menggabungkan ide Izutsu dengan tafsir tematik (maudhu')yang merupakan bagian dari khazanah pemikiran khas Islam. Kami berupaya untuk menjawab empat kritik di atas berkaitan dengan sifat, legitimasi, referensi, dan kegunaan penelitian semantik Alquran Izutsu.

Berdasarkan kajian pendahuluan, observasi dan berbagai eksperimen yang telah kami lakukan selama 10 tahun lebih sebagai pengajar mata kuliah semantik Alquran, kami merumuskan rancang bangun yang baru sebagai model penelitian semantik Alquran yang lebih aplikatif, efektif, efesien dan lebih berguna serta dapat menjawab empat kritik yang selama ini dialamatkan pada bidang kajian semantik Alquran.

\section{Semantik Alquran Model Ensiklopedik}

Semantik yang peneliti tawarkan disebut semantik ensiklopedik. Semantik ensiklopedik adalah semantik yang diarahkan untuk menggali makna kata-kata dalam Alquran secara ensiklopedik. Tujuan dari semantik model ini adalah untuk meng-upgrade karya-karya klasik yang sejenis dari turats seperti Mu'jam Mufradat li Alfadz. Alquran karya al Raghib al Isfihani, dengan pendekatan semantik modern. Semantik Alquran model Ensiklopedik akan fokus memperbaiki kekurangan-kekurangan semantik Alquran model Izutsu seperti yang diidentifikasi oleh Albayrak. Pertama, tujuannya bukan untuk mencari tahu inti gagasan Alquran, melainkan untuk menelisik lebih dalam gagasan-gagasan partikular dalam Alquran. Oleh karena itu, berbeda dengan Izutsu yang bergerak dari konsep-konsep partikular menuju keseluruhan (generalisasi), Semantik Alquran model Ensiklopedik bergerak dari keseluruhan menuju pemahaman yang mendalam mengenai konsep-konsep partikular dalam Alquran. Ia bersifat lebih eksploratif

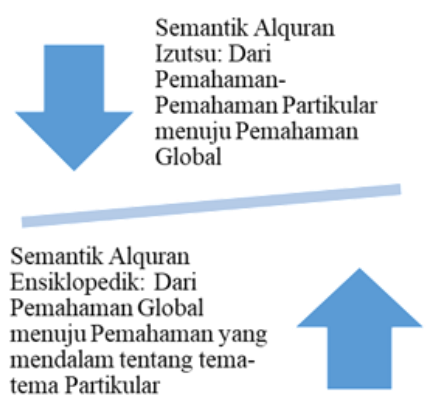

Gambar 1: Perbedaan Konseptual Analisis Semantik Alquran Izutsu dan Semantik Alquran Ensiklopedik 
$\underline{\text { Kedua, }}$, pendekatan yang digunakan Izutsu masih berbasis strukturalisme khas Barat. Namun demikian, dalam semantik Alquran model Ensiklopedik, pendekatan struktural ini hanya akan digunakan sebagai alat analisis untuk membantu metode tafsir maudhu'i yang telah menjadi salah satu metode khas Islam yang biasa dipakai untuk menafsirkan Alquran.

Ketiga, referensi yang digunakan tidak hanya bertumpu pada syair-syair Arab Jahiliyah saja, namun juga melibatkan secara ekstensif kitab-kitab mu'jam, hadits dan tafsir yang mu'tabar.Hal ini untuk menutupi kekurangan analisis semantik Alquran versi Izutsu yang dianggap mengabaikan al-turats al-islämī.

Keempat, analisis semantik Alquran model Ensiklopedik ini akan diarahkan untuk menjawab tiga pertanyaan mendasar mengenai konsep-konsep dalam Alquran, yakni apa, bagaimana dan mengapa. Setiap hasil penelitian semantik Alquran diharapkan dapat menjawab apa hakikat konsep yang sedang dikaji, bagaimana cara melaksanakan atau menjauhinya, dan alasan mengapa harus melaksanakan atau menjauhinya. Hal ini akan membuat hasil penelitian semantik Alquran lebih berguna bagi para pembacanya.

\section{Landasan Teori Kajian Semantik}

Desain analisis semantik Alquran versi Ensiklopedik adalah kombinasi dari analisis struktural khas Barat dan metode tafsir maudhu'i khas Islam.Oleh karena itu, landasan teoritisnya sebagian bersumber dari Barat, sebagian lagi dari khazanah dunia Islam. Untuk lebih jelasnya landasan teoritis semantik Alquran versi Ensiklopedik ini akan dipaparkan secara bertahap sesuai alur waktu.

Gagasan mengenai "studi tentang makna" sebenarnya sudah muncul sejak tahun 1825 dalam kuliah yang disampaikan oleh Karl. C. Reisig di universitas Halle. ${ }^{21}$ Pada tahun 1880-an "studi tentang makna" ini mulai dikenal dengan istilah semantik dan berkembang menjadi dua kecendrungan. Pertama, gagasan Arsene Darmesteter pada tahun 1886 yang mengarahkan perhatiannya pada masalah relasi kata dengan kata-kata yang lainnya. ${ }^{22}$ Kedua, gagasan Michel Breal pada tahun 1897 yang mengarahkan perhatiannya pada masalah perubahan makna kata. ${ }^{23}$

Walaupun berbeda, kedua gagasan ini sebenarnya saling melengkapi, karena suatu kata memang baru bermakna saat ia berrelasi dengan kata-kata yang lain. Konsekuwensinya jika relasi suatu kata berubah, maka berubah pula makna

${ }^{21}$ Stephen Ullmann, Semantic an Introduction to the Science of Meaning (Oxford: Basil Backwell, 1972), 5.

${ }^{22}$ Arsene Darmesteter, The Live of The Words as The Symbols Of Ideas (London: Kegan Paul, Trench \& CO.-Paternoster Square, 1886).

${ }^{23}$ Michel Bréal, Semantic Studies in The Science of Meaning, trans. Nina Cust (New York: Henry Holt \& Co, 1900), 99. 
kata tersebut. Masalah relasi kata dan perubahan makna yang ditimbulkannya ini dibahas lebih jauh oleh Ferdinand de Saussure pada awal abad ke-20.Ia berkata: "Language is a system of interdependent terms in which the value of each term results solely from the simultaneous presence of the others. ${ }^{124}$

Pada tahun 1930-an perhatian semantik terhadap masalah perubahan makna suatu kata dari zaman ke zaman dan sebab musabab terjadinya terus menjadi pusat perhatian. Kajian semacam ini disebut pendekatan historis. Contoh penelitian semantik dengan pendekatan ini adalah buku karya Gustav Stern "Meaning and Change of Meaning with Special Reference to the English Language". ${ }^{25}$ Buku itu membahas secara empiris perubahan makna kata-kata dalam bahasa Inggris dari zaman ke zaman. Penelitian semantik yang bersifat historis ini telah membawa semantik pada masalah yang lain. Kalau memang makna sebuah kata itu berubah dari zaman ke zaman, maka apa indikator dari adanya perubahan itu?

Masalah ini kemudian dipecahkan oleh hasil penelitian yang dilakukan oleh Jost Trier, bahwa perubahan makna suatu kata ternyata ditandai oleh perubahan relasi kata itu, yakni oleh perubahan struktur kosakata yang melingkupi kata tersebut. Jost Trier menyebut perubahan struktur kosakata ini dengan dengan istilah perubahan "medan makna." Dalam sebuah monograf, Jost Trier memberikan ilustrasi sebagai berikut: Pada tahun 1200-an di Jerman dikenal kata wisheit yang berarti berarti bijaksana. Kebijaksanaan yang dimaksud berkaitan dengan dua hal yakni kusnt yang berarti pengetahuan dan list yang berarticerdik. Pada tahun 1300-an terjadi perubahan makna kata wisheit. Perubahan itu ditandai oleh perubahan struktur kosakatanya. Pada tahun 1300an kosakata wisheit tidak lagi berhubungan dengan pengetahuan (kunst)dan kecerdikan (list), melainkan dengan keshalehan, pengalaman religius atau pengalaman mistis. Mengapa perubahan ini terjadi? Setelah diselidiki perubahan makna ini ternyata berhubungan dengan perubahan realitas dan alam pikiran yang terjadi di Jerman saat itu. ${ }^{26}$ Temuan Jost Trier tersebut menunjukkan pengaruh perubahan realitas dan alam pemiikiran terhadap bahasa. Bahwa jika realitas dan alam pikiran manusia berubah, maka hal itu akan berimplikasi pada perubahan makna bahasa mereka.

Gagasan Jost Trier ini kemudian diterima secara luas. Namun rupaya para ahli semantik menemukan gagasan lain yang lebih revolusioner. Sekarang

\footnotetext{
${ }^{24}$ Ferdinand de Saussure, Course in GeneralLinguistics, trans. Wade Baskin (London: Owen, 1960), 114.

${ }^{25}$ Stern, Gustav, Meaning and Change of Meaning with Special Reference to the English Language (Gothenburg: Goteborg Hogskolas Arsskrift XXXVIII, 1931).

26J.Trier, Der Deutche Wortschatz Im Sinnbezirk Des Verstandes (Heidelberg, 1931).
} 
mereka mulai berpikir bahwa tidak hanya alam pikiran yang bisa merubah bahasa, tapi sebaliknya bahasa juga dapat mengubah dan membentuk alam pikiran. Gagasan ini mula-mula dipromosikan oleh Edwar Sapir lalu disempurnakan oleh muridnya yang bernama Benjamin Lee Whorf. Oleh karena itu gagasan ini kemudian diberi nama "hipotesis Sapir-Whorf." Menurut teori ini bahasa memang dibentuk oleh manusia.Tapi manusia kemudian mewariskan bahasa itu kepada generasi selanjutnya.Melalui bahasalah generasi tua membentuk wawasan generasi muda.Sebagai akibatnya generasi muda, disadari ataukah tidak, melihat memahami dan menyikapi realitas melalui bahasa yang diajarkan oleh leluhurnya.Melalui warisan bahasa itulah generasi muda saat ini melihat, memahami dan menyikapi kenyataan ${ }^{27}$ Inilah yang dimaksud bahwa bahasa membentuk alam pikiran dan realitas yang kita hadapi. "For men imagine that their reason governs words, while, in fact, word react upon understanding. 28

Michel Foucault melalui pelbagai tulisannya telah berhasil membuktikan bagaimana bahasa dalam bentuknya sebagai wacana (discourse)bisa mengatur pikiran kemudian mengubah realitas. Wacana adalah omongan-omongan yang serius mengenai suatu hal. Selain berupa pembicaraan ilmiah, wacana juga mencakup pembicaraan sehari-hari.Mula-mula sangat cair; Siapapun boleh mengatakan apapun. Lama kelamaan muncul suatu institusi yang dianggap otoritatif. Wacana pun mulai mengental dan mengeras. Kini hanya institusi itu yang punya hak berbicara. Melalui wacana yang ia produksi, institusi ini mengontrol cara publik melihat kenyataan. Ia menentukan apa yang boleh, benar dan wajar; serta apa yang tabu, salah dan edan mengenai suatu hal. ketentuan ini disebut episteme. Episteme demikian kuat, namun tidak kentara karena telah diterima publik sebagai hegemoni. ${ }^{29}$ Temuan-temuan Foucault ini telah membuktikan bahwa "hipotesis Sapir-Whorf" sungguh-sungguh dapat terjadi, yakni bahwasanya bahasa dalam bentuknya sebagai wacana, pada akhirnya dapat mengubah pikiran dan kenyataan.

Lalu apa gunanya teori-teori itu bagi studi Alquran. Perlu diketahui bahwa apa yang disebut discourse (wacana) oleh Foucault pada dasarnya identik dengan da'wah dalam khazanah pemikiran Islam. Bukankah da'wah adalah omong-omong yang serius yang dimaksudkan untuk menjelaskan mana yang baik, mana yang buruk; mana yang boleh, mana yang tidak boleh; mana yang wajar mana yang tidak wajar.Dahulu dengan omong-omong seperti ini Rasulullah Saw. berhasil mengubah alam pemikiran bangsa Arab dari jahiliyah menjadi Islam, lalu kemudian seiring dengan perubahan alam pikiran mereka,

\footnotetext{
${ }^{27}$ Benjamin L. Whorf, Language, Thought and Reality: Selected Writing of Benjamin L. Whorf, ed. J.B. Carroll (Cambridge: M.I.T. Press, 1956), 212.

${ }^{28}$ Lord Bacon, Novum Organum (New York: P.F. Collier and Son, MCMI, n.d.), 31.

${ }^{29}$ Foucault, Michel, Archeology of Knowledge and The Discourse on Language (New York: Pantheon Books, 1971).
} 
berubah pula realitas masyarakat Arab saat itu dari sekedar bangsa badewi yang tidak diperhitungkan menjadi bangsa berperadaban tinggi, yang selama berabadabad menjadi kekuatan adidaya di dunia. Semua dilakukan dengan bahasa, omong-omong atau wacana. Seandainya apa yang dahulu diwacanakan oleh Rasulullah Saw. dapat direstorasi, ditulis ulang dan didakwahkan kembali, maka tentu perubahan yang kurang lebih sama juga akan terjadi.

Hal ini sejalan dengan teori doublemovement-nya Fazlur Rahman. Menurutnya apa yang dahulu berhasil diwujudkan secara aktual pada masa Rasulullah, tentu bisa diwujudkan lagi pada masa kini dengan dua cara, yakni: (1) kembali ke masa Rasulullah dan merestorasi konsep-konsep inti yang dahulu diwacanakan oleh Rasulullah Saw., (2) kembali ke masa kini dan berupaya sebisa mungkin menerapkan konsep-konsep itu sesuai kondisi zaman. Untuk kepentingan ini Fazlur Rahman memilih hermeneutik sebagai alat metodologisnya. ${ }^{30}$ Peneliti meyakini bahwa gagasan itu akanlebih sukses dilaksanakan seandainya saja Fazlur Rahman bertumpu pada semantik, bukan pada hermeneutik.

Upaya dari tradisi Islam sendiri untuk merestorasi konsep-konsep inti yang dulu diwacanakan oleh Rasulullah Saw. sudah diupayakan sejak tahun 1970-an di antaranya melalu metode tafsir maudhu'i. Alquran dengan bantun metode ini diharapkan dapat menjawab berbagai pertanyaan mengenai tematema tertentu yang dianggap penting dan relevan dengan kebutuhan zaman modern. Dengan adanya metode tafsir maudhu' $i$ isi kandungan Alquran dapat disajikan secara ensiklopedik dari tema "a" sampai "z."

Ide utama tafsir maudbu'i adalah mengumpulkan ayat-ayat Alquran mengenai tema tertentu, kemudian menghubung-hubungkan ayat-ayat itu satu sama lain, dengan harapan diperoleh wawasan Alquran yang relatif komprehensif mengenai tema tersebut. ${ }^{31}$ Namun metode tafsir maudhu'ini memiliki kelemahan. Kelemahannya terletak pada minimnya metode analisis untuk menghubung-hubungkan ayat-ayat itu satu sama lain. Sampai saat ini hal itu masih semata-mata diserahkan kepada kegeniusan mufasir saja. Di titik inilah semantik Alquran dapat berperan, ia dapat dijadikan sebagai metode analisis yang lebih terukur dan bisa dipergunakan bersama-sama oleh mereka yang ingin menafsirkan Alquran secara maudhu'i.

${ }^{30}$ Fazlur Rahman, Islam and Modernity, Transformation of an Intellectual Tradition (Chicago: University of Chicago Press, 1984), 5-7.

${ }^{31}$ Abd al-Hayy al-Farmawi, Al-Bidayah Fi al-Tafsir al-Maudbu'i Dirasah Manbajizah Mawdbu'iyah (Kairo: Mathba'ah al-Hadlarah al-Arabiyah, 1997). 
Namun demikian, ada satu hal yang patut dicatat. Mengingat wataknya yang strukturalis, semantik Alquran tidak dapat digunakan untuk menganalisis tema-tema asing yang asing bagi Alquran. Misalnya saja ia tidak dapat digunakan untuk menganalisis tema profesionalisme, demokrasiatau psikologi dalam Alquran. Ini karena ketiga kata tersebut tidak tersurat dalam Alquran. Dengan asumsi bahwa wawasan Alquran adalah sebuah gestalt, maka tugas semantik Alquran hanyalah mengungkap makna dari tema-tema atau kata-kata yang memang berasal dari Alquran sendiri.

\section{Langkah-langkah Penelitian Semantik AlquranVersi Ensiklopedik}

Langkah-langkah penelitian semantik Alquran versi Ensiklopedikadalah perpaduan dari metode tafsir mudhu'i dan analisis semantik.Ia dapat dibagi menjadi enam tahap. Tahap pertama adalah menentukan kata yang akan diteliti(choosing)dan menjelaskan kenapa tema itu dipilih (profiling). Tahap kedua, mengumpulkan ayat-ayat yang memuat kata tersebut berikut derivasinya (collecting). Tahap ketiga, adalah riset. Riset tersebut bertujuan untuk mengumpulkan bahan-bahan yang diperlukan untuk menentukan makna dasar dan makna relasional dari kata yang sedang diteliti. Untuk kepentingan itu ada empat sumber yang harus dikaji yaitu: kamus, syair, ayat Alquran dan tafsir. Peneliti harus memahami berbagai informasi penting yang terkandung dalam keempat sumber tersebut. Proses riset ini meliputi empat langkah yaitu: dirasah ma fi al-ma'ajim (kajian Kamus), dirasah ma qabla al-quran (kajian syair Arab Jahiliyyah), dirasah ma fi al-quran (kajian magza ayat-ayat Alquran), dan dirasah ma bawla al-quran (kajian kitab tafsir mu'tabar). Tahap keempat, menentukan makna dasar dan makna relasional. Tahap kelima, membuat medan makna untuk menggambarkanmakna dasar dari kata yang sedang diteliti, makna relasional kata itu pada masa jahiliyah, dan makna relasionalnya pada masa Alquran diturunkan. Tahap terakhir, dari penelitian semantik Alquran adalah menulis konsep. Pada tahap ini, peneliti sudah memiliki bahan-bahan yang diperlukan dan telah memahaminya secara matang, sehingga ia siap untuk menuliskan secara komprehensif konsep di balik kata yang sedang ditelitinya. Harus ditegaskan kembali di sini bahwa hasil dari penelitian semantik adalah sebuah konsep hasilkristalisasi dari weltanschaunng (wawasan khas) yang tersembunyi di balik kata-kata yang terdapat dalam Alquran. ${ }^{32}$

32 Toshihiko Izutsu, Ethico-Religious Concepts in Qur an (Montreal-London: McGillQueen's University Press, 2002), 9. 


\section{Contoh Aplikasi Semantik AlquranModel Ensiklopedik}

Kata mațar dalam Alquran

Kata matar dan derivasinya dalam Alquran disebutkan 15 kali dalam 5 bentuk. Kata ini tersebar di 9 ayat dalam 9 surat. ${ }^{33}$ Tujuh ayat diturunkan di Mekkah yaitu: QS al-A'rāf [7]: 84; QS Hūd [11]: 82; QS al-Hijr [15]: 74; QS ashShu'arā [26]: 173; QS an-Naml [27]: 58; QS al-Furqan [25]: 40; QS al-Ahqaf [46]: 24. Sedangkan dua ayat lagi diturunkan di Madinah yakni: QS al-Anfāl [8]: 32 dan QS an-Nisā [4]: 102.

Sebaran ayat-ayat tentang matar dan derivasinya dapat dilihat dalam tabel berikut ini:

\begin{tabular}{|c|c|c|c|}
\hline No & Lafadz & Frekwensi & Alquran \\
\hline 1. & أَْْطَرْنَاَ & 5 kali & $\begin{array}{l}\text { QS:7:84; } \\
\text { QS:11:82; } \\
\text { QS:15:74; } \\
\text { QS:26:173; } \\
\text { QS:27:58 }\end{array}$ \\
\hline 2. & فَأمِْْر & 1 kali & QS:8:32 \\
\hline 3. & أمْطِرت & 1 kali & QS:25:40 \\
\hline 4. & مَطَر & 7 kali & $\begin{array}{l}\text { QS:4:102; } \\
\text { QS:25:40; } \\
\text { QS:26:173; } \\
\text { QS:27:58; } \\
\text { QS:7:84 }\end{array}$ \\
\hline 5. & مُمْطِرُنَاَ & 1 kali & QS:46:24 \\
\hline
\end{tabular}

Tabel 1: Sebaran ayat-ayat tentang matar dan derivasinya

Makna Dasar al-Mațar

Makna dasar adalah makna yang secara laten selalu melekat pada arti suatu kata. Untuk mencari makna dasar, kamus-kamus bahasa Arab yang mu'tabar dapat menjadi referensi. Dalam kesempatan ini penulis akan merujuk kepada Lisān al-A'rab, Mu'jam Mufradhät Fì Gharīb Alqurān, Mu'jam al-Furuq alDiläliyyah.

${ }^{33}$ Muhammad AbdulBaqi, Mu'jam Mufahras LiAlfaz. Alquran al-Karim (Kairo: Dar alHadis, 2007), 668. 
194 | AL QUDS : Jurnal Studi Alquran dan Hadis vol. 4, no 2, 2020

Kata matar merupakan gabungan dari huruf mim (ק), ta(b) dan $r a(\jmath) .{ }^{34}$ Secara literal matar bermakna hujan yakni air yang turun dari langit. Hal ini sebagaimana yangdisebutkan Ibn Manzūur dalam Lisān al-' Arāb

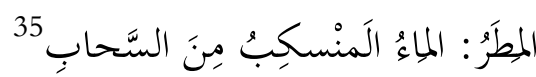

matar adalah air yang tumpah dari awan"

Begitu pula yang dikatakan oleh al-Rāghib al-Ișfahāniy dalam Mu'jam Mufradhat fi Gharib Alquran:

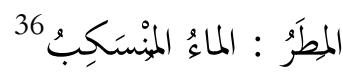

mațar adalab air yang tercurab"

Muhammad Daud juga menyebuthal yang sama dalam Mu'jam al-Furūq al-Dilāiliyyah

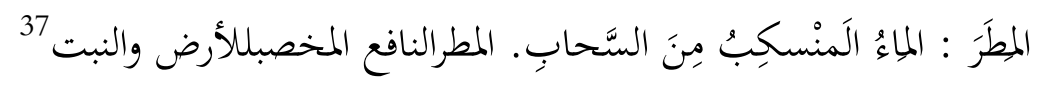

mațar: air yang tumpah dari awan. matar memberikan manfaat menyuburkan tanabdan tetumbuban.

Dari kata matar yang bermakna air yang turun dari langit tersebut, muncul makna konotatif yaitu hujan batu seperti yang dikatakan oleh Ibn Manzūur dalam Lisān al-A'rāb:

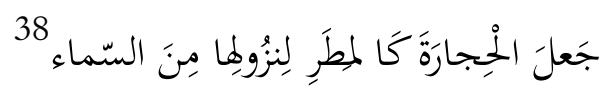

bujan batu dianggap sebagai mațar, karena turunnya dari langit” Dilaliyyah:

Hal ini diperjelas oleh Muhammad Daud dalam mujam al-Furuq al-

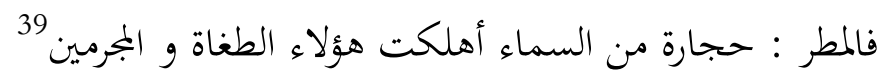

${ }^{34}$ Ahmad Ibn Fāris, Mu’jam Maqāyìs Lughah (Beirut: Dār al-Fikr, n.d.), 332.

35Ibn Mandzur, Lisān Al-A'rab, vol. v. 5 (Baerut: Dār al-Shādir, 2010), 178.

${ }^{36}$ Al-Raghib al-Ishfahaniy, Mu'jam Mufradat Fi Gharib Alqurān (Maktabah Nazar Musthafa al-Bazz, n.d.), 607.

${ }^{37}$ Muhammad Muhammad Dāud, Mujam Al-Furuq Diläìiyah Fì Alqurān al-Karim (Kairo: Dār al-Gharīb, 2008), 353.

${ }^{38}$ Ibn Mandzur, Lisān Al-A'rab, v. 5:178.

${ }^{39}$ Dāud, Mujam Al-Furuq Dilāìyah Fì Alqurān al-Karìm, n.d., 354. 
mațar adalah bujan batu dari langit yang membinasakan orang-orang yang melampaui batasdan para pendosa.

Berdasarkan data-data tersebut, dapat ditarik suatu temuan bahwa makna dasar kata matar adalah كل مَا ينْسكِبُ مِنَ السماء. Matar adalah sesuatu yang turun dari langit entah itu air yang membawa manfaat atau batu yang membawa adzab. Berikut ini skema makna dasar kata matar.

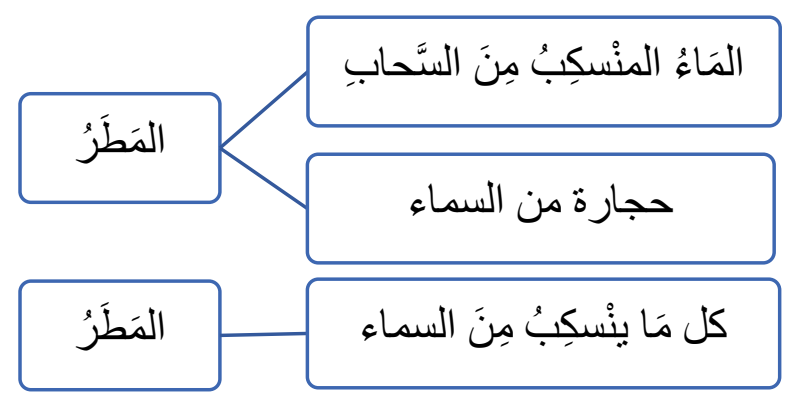

Gambar 2: Skema makna dasar kata matar

Makna Relasional al-Mațar Pra Qur`an

Makna relasional adalah makna yang lahir ketika suatu kata diletakkan dalam susunan kalimat bersama kata-kata lainnya, atau dalam suatu konteks pembicaraan atau situasi tertentu. Untuk mencari makna relasional pra-Qur'an, sya'ir-sya'ir Arab jābiliyyah adalah referensi yang utama. Kata matar pada masa jähiliyyah sudah digunakan oleh orang-orang Arab dalam syair-syair mereka. Hal ini sangat penting untuk dilihat agar mengetahui penggunaan kata tersebut pada masa itu. Berikut syair-syairnya:

Syair Pertama

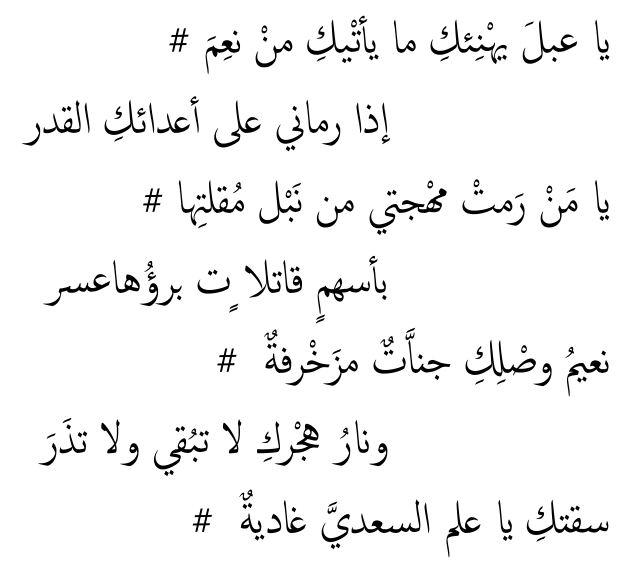


196 | AL QUDS : Jurnal Studi Alquran dan Hadis vol. 4, no 2, 2020

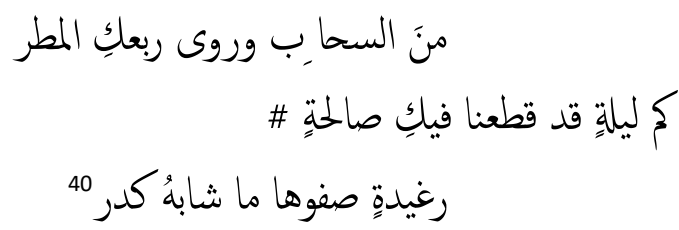

Wahai Abla gadisku, semua karunia yang ada padamu akan memujimu \# Jika kau lepas aku untuk mengalabkan musuh-musubmu

Wabai yang memanah tepat di jantungku\# dengan panahasmara yang sulit dibindari

Kenikmatan bersamamu adalah surga yang indah \# sedang siksaan jaub darimu adalah neraka yang tidak lenyap dan tidak lelap

Di pagi hari, wahai tanda kebahagian, engkau diberi minum oleh air\# dari awan, sedang bujanpun menyirami sekelilingmu

Tak terhitung malam yang telah kita tempub bersama dengan penub kedamaian \# sedangketulusannya begitu jernih tanpa ada keraguan.

Dalam syair di atas Antarah Bin Syadad membicarakan seseorang yang bernama Abla. Dalam syair tersebut dia menggambarkan kebahagiaan dan cinta terhadap kekasihnya. Dari syair di atas matar dapat diartikan hujan yang turun dari awan yang menghilangkan dahaga karena airnya dapat diminum.

Syair Kedua

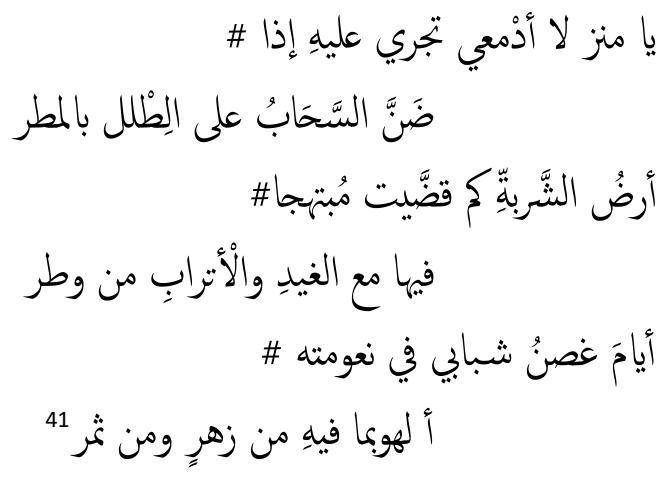

Wahai sumber mata air, airilah tanah ini \# kalau sekiranya awan menahan hujan dalam waktu yang lama

Tanah Syarbah, oase tempat ku habiskan masa kecilku dengan riang\# Bersamatemanteman sebaya dari negeri $W$ ațar

Hari-hari ketika masa muda karena kepolosannya masib belum memperhatikan bunga dan buah yang tumbuh di dalamnya.

${ }^{40}$ Antarah bin Syadad, Diwan Antarah Bin Sadad, ed. Amin Said (Kairo: alMaktabah al-Tijariyah al-Kubra, n.d.), 66-67.

${ }^{41}$ Ibid., 71. 
Syair di atas Antarah membicarakan kampung halamannya yang indah tempat ia menghabiskan masa kecilnya. Digambarkan dalam syairnya walaupun awan tidak menurunkan hujan akan tetapi mata air tetap mengalir dan tempat itu biasa dijadikan tempat minum. Oase tempat bunga dan buah-buahan tumbuh dengan subur.

Syair Ketiga

$$
\begin{aligned}
& \text { ألذُ عندي مما حوتهُ يدي \# } \\
& \text { من اللآلي والمال والبدرَ }
\end{aligned}
$$

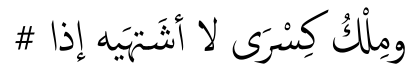

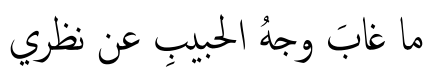

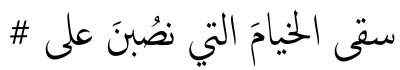

$$
\begin{aligned}
& \text { شربِّة الْأنسِ وابِلُ المطر } \\
& \text { منازلٌ تطلعُ البدور بها } \\
& \text { مبرقعاتِ بظلمةِ الشَّعر }
\end{aligned}
$$

Aku puas dengan apa yang aku peroleh dengan kedua tanganku \# Entah itu permata, harta ataupun pundi-pundi emas

Kerajaan kaisar Persia pun tidak membuatku tertarik \# apabila wajah kekasib hilang dari pandangan

Hujan deras menyiram perkemahan yang didirikan \# memberi minum umat manusia

Kemah-kemah kediaman (pemuda-pemudatampan laksana) purnama \# lagi gagah perkasa dengan rambut yang bitam pekat. ${ }^{42}$

Syair di atas membicarakan tentang kemah-kemah yang ada pada masa Jabiliyyah yang di guyur oleh hujan, dan hujan tersebut menjadi sumber minum orang-orang yang hidup disana.

Setelah melihat syair-syair tersebut, dapat ditarik kesimpulan bahwa kata matar pada masa Jabiliyyah bermakna hujan air dan memiliki kesan positif. Hal ini dibuktikan dengan isi syair yang menggambarkan keindahan, oase, air minumdan gambaran alam yang sejuk. Berikut skema medan semantik kata matar pada masa Pra Quranik:

42Ibid., 75. 


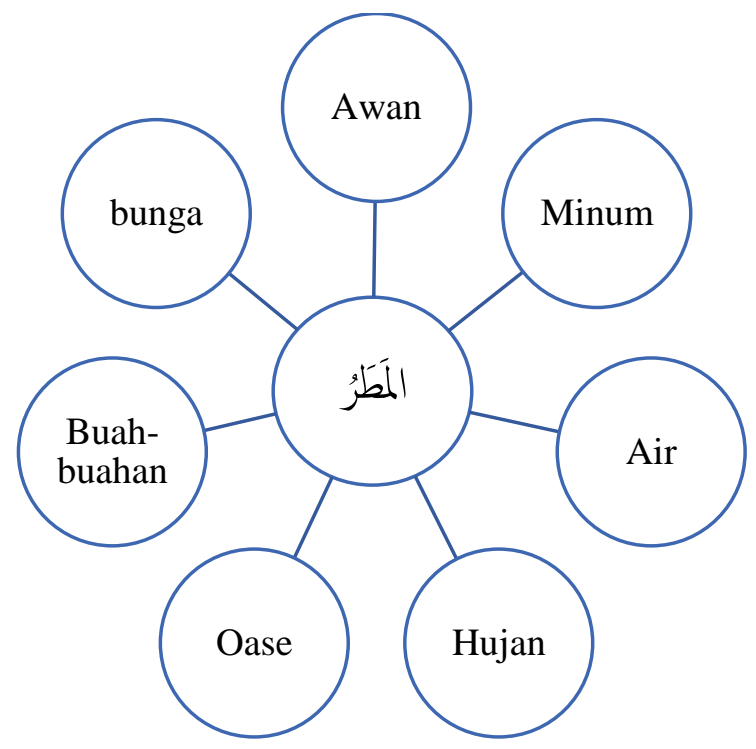

Gambar 3: Skema medan semantik kata mațar pada masa Pra Quranik

Makna Relasional Mațar dalam Qur`an

Relasi makna Matar dan derivasinya dalam Alquran sangatlah berbeda, jika dibandingkan dengan masa Pra Quran. Kata matar dalam Alquran memiliki kesan negatif. Hal ini bisa dibuktikan dengan ayat-ayat Alquran yang memuat kata matar yang seluruhnya berkonotasi buruk. Perubahan ini sesungguhnya menunjukkan telah terjadinya pergeseran makna kata matar dari masa pra Qur'an ke masa Alquran; dari yang semula maknanya positif di pra Qur'anik menjadi makna negatif di dalam Al-Qur'an. Pernyataan ini didasarkan pada hasil telaah kami berkaitan dengan kata matar dalam Alquran yang identik dengan halhal yang negatif, berikut pemaparannya:

Pertama, kata matar yang berkaitan dengan kesusahan. Kata "matar" dalam sebuah ayat telah direlasikan dengan kata أذًَّ yang berarti kesusahan. Hal ini terdapat dalam Q.S. an-Nisā [4]: 102 sebagai berikut:

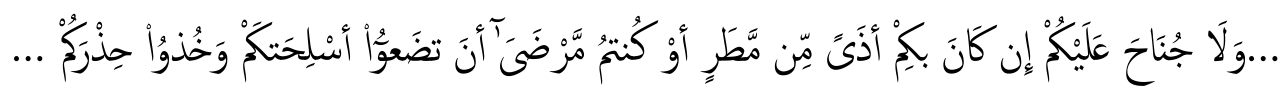

$$
\text { 率 } 1 \cdot \text { r }
$$

...Dan tidak mengapa kamu meletakkan senjata-senjatamu, jika kamu mendapat suatu kesusahankarena bujan atau karena kamu sakit, dan bersiap siagalab kamu...

Dalam ayat ini kata "matar" berarti hujan air, namun ia disandingkan dengan kata أَذَىً. Ini artinya hujan yang tersebut membawa kesusahan. Ayat ini secara khusus berbicara tentang shalat dalam peperangan. Dalam keadaan 
perang, kaum muslimin tetap harus shalat sambil menyandang senjata. Namun ketika sedang hujan kaum muslimin diberikan keringanan untuk tidak menyandang senjata, karena hujan biasanya akan merusak senjata. Hal ini menimbulkan resiko besar karena bisa saja musuh menyerang secara tiba-tiba. ${ }^{43}$

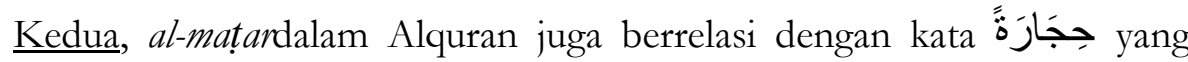
berarti (batu), seperti terungkap dalam QS Hūd [11]: 82 dan QS al-Hijr [15]:74:

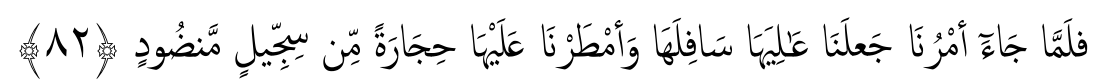

Maka ketika keputusan Kami datang, Kami menjungkirbalikekannya (negeri kaum Lut), dan Kami bujani mereka bertubi-tubi dengan batu dari tanah yang terbakar.

Seperti yang telah disinggung sebelumnya bahwa kata "matar" dalam Alquran memiliki kesan yang negatif, karena yang turun bukan berupa air, melainkan batu. Batu yang turun ini berupa batu dari sijjil.

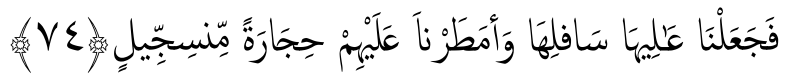

Maka Kami jungkirbalikekan (negeri itu) dan Kami bujani mereka dengan batu dari tanah yang keras".

Sijjil berasal dari bahasa Persia yang memiliki arti batu dari tanah liat atau tanah basah. Dalam tafsirnya Quraish Shihab menyebutkan bahwa sijjil adalah batu bercampur tanah atau tanah bercampur air lalu membeku dan mengeras menjadi batu. ${ }^{44}$

Ketiga, kata matar dalam Alquran juga berrelasi dengan kata الَمُجْرِمِيْنَ yang berarti orang-orang yang berbuat dosa seperti yang terungkap dalam QS al-A'rāf [7]: 84 berikut ini:

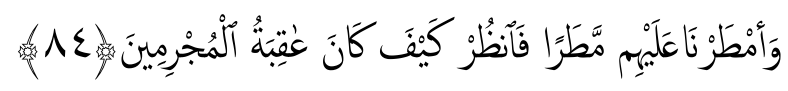

Dan Kami bujani mereka dengan bujan (batu). Maka perhatikanlah bagaimana kesudahan orang yang berbuat dosa itu.

QS. al-A'rāf [7]: 84 ini juga berkaitan dengan kisah kaum Nabi Lut yang selalu berbuat dosa. Nabi Lut dan kaumnya tinggal di sebuah negeri bernama Sodom.Mereka gemar berbuat dosa.Maksiat mereka yang paling menonjol adalah perbuatan homoseksual.Hal itusudah menjadi suatu kebudayaan bagi

${ }^{43}$ M. Quraish Shihab, Tafsir Al-Misbab: Pesan,Kesan Dan Keserasian Alquran, vol. v.2 (Jakarta: Lentera Hati, 2002), 691.

${ }^{44} \mathrm{Ibn}$ 'Ashūr, Tafsìr Al-Tahrìr Wa al-Tanwìr, vol. v.12 (Tunis al-Dār al-Tūnisiyah li alNasyr, 1984), 135. 
mereka. ${ }^{45}$ Hingga akhirnya mereka diadzab dengan tiga perkara: Petir yang dahsyat, kampung mereka dijungkir-balikan, dan Allah menghujani mereka dengan hujan batu. ${ }^{46} \mathrm{Kata}$ "matar" jika disandingkan dengan kata الَهُجْرِرِيْنَ (para pendosa) memiliki makna hujan batu.

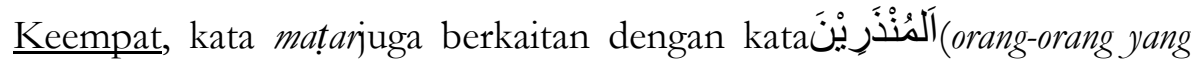
telah diberi peringatan), seperti terdapat dalam QSash-Shu'arä [26]: 173 dan QS. alNaml [27]: 58yang redaksinya persis sama:

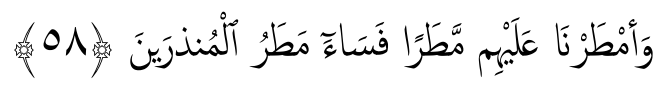

Dan Kami bujani mereka (dengan bujan batu), maka betapa buruk. bujan yang menimpa orang-orang yang telah diberi peringatan itu.

Kata mațar dalam ayat ini memiliki makna hujan yang sangat buruk yaitu hujan batu. Disebut hujan yang sangat buruk dikarenakan dari sekian banyak hal yang mungkin jatuh dari langit, batulah yang Allah kirimkan untuk menghancur leburkan kaum Sodom. Semua terjadi karena mereka mengabaikan peringatan Nabi Lūt untuk segera meninggalkan dosa dan kebiasaan buruk mereka. Namun, perbuatan keji itu terus mereka lakukan, hingga akhirnya Allah Swt, menurunkan azab kepada mereka. ${ }^{47}$

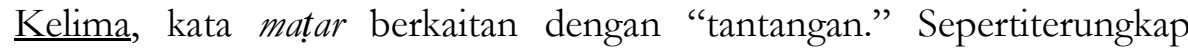
dalam QS al-Anfāl [8]: 32 dan QS al-Ahqāf [46]: 24.Kata mațar dalam kedua ayat ituberelasi dengan kalimat أَوِ ائتنِنَاَ بِعَذَابِ (datangkan kepada kami aحab), dan kalimat مَأسنْتْجَلْنُُْ (azab yang kalian minta lekas datangnya).

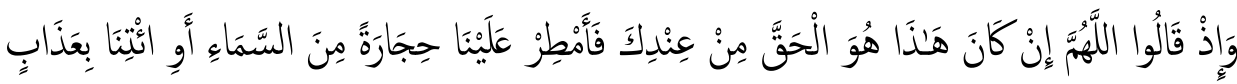

$$
\begin{aligned}
& \text { 票 }
\end{aligned}
$$

Dan (ingatlab), ketika mereka (orang-orang musyrik) berkata: "Ya Allah, jika betul (Alquran) ini benar dari sisi Engkau, maka bujanilah kami dengan batu dari langit, atau datangkanlah kepada kami azab yang pedih.

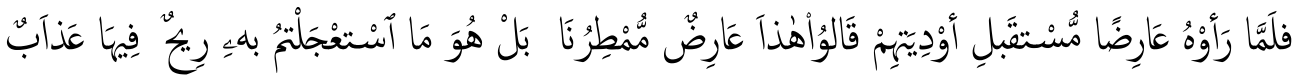

$$
\begin{aligned}
& \text { 尔 }
\end{aligned}
$$

${ }^{45}$ Ibn Katsir, Tafsiìr Al-Qur'ān al- Ażìm. Rìyadh, vol. v.3 (Dār Ṭoyyibah li al-Nasyr wa alTawzì', 1999), 444-46.

${ }^{46}$ Al-Marāgīi, Aḥmad Mustāeāā, Tafsìr Al-Marāgì, vol. 8 (Mesir: Syirkah Maktabah wa Maṭba'ah Muștafā al-bBābī al-Ḥalabī wa Awlaāduh, 1946), 303-7. 1994), 572.

${ }^{47} \mathrm{Al}-\mathrm{T}$ abarī, Jämi' al-Bayān 'an Ta 'wìl Āyì al-Qur 'àn, vol. 5 (Baerut: Mu’assasah al-Risālah, 
Maka ketika mereka melibat azab itu berupa awan yang menuju ke lembah-lembah mereka, mereka berkata, "Inilah awan yang akan menurunkan bujan kepada kita."(Bukan!)Tetapi itulah azab yang kamu minta agar disegerakan datangnya (yaitu) angin yang mengandung azab yang pedih.

QS al-Anfāl [8]: 32 berisi tantangan kaum musyrikin agar azab segera datang. Bahkan secara spesifik minta dihujani dengan batu. Sementara diQS alAhqāf [46]: 24 secara verbatim Alquran menolak anggapan kaum Hūd bahwa awan yang datang itu akan mencurahkan hujan. Alquran mengatakan bahwa awan itu justru angin topan. ${ }^{48}$ Kata matar yang dikaitkan dengan tantangan orang kafir atau musyrik berrelasidengan azab berupa bencana alam yang dahsyat.

Keenam, kata matar dalam Alquran juga berelasi dengan kata " لََ يَزْجُوْنَ "نشُورًا (orang-orangyang tidak mengharapkean hari kebangkitan), Dalam QS al-Furqān [25]: 40 Allah Swt. berfirman:

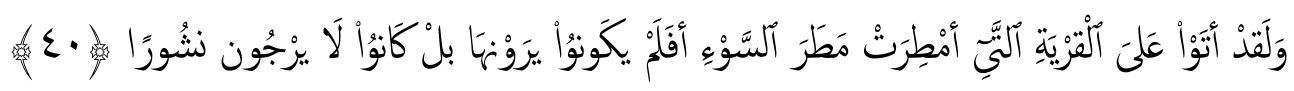

Dan sungguh, mereka (kaum musyrik. Mekah) telah melalui negeri (Sodom) yang (dulu) dijatubi bujan yang buruk (bujan batu). Tidakkah mereka menyaksikannya? Babkan mereka itu sebenarnya tidak mengharapkan hari kebangkitan.

Ayat ini menjelaskan tentang kaum Musyrikin yang tidak mau mengambil pelajaran dari kaum Nabi Luth yang telah terlebih dahulu dibinasakan oleh Allah Swt. dengan hujan batu akibat kedurhakaan mereka. Hal itu dikarenakan kaum musyrik tidak mempercayai dan tidak mengharapkan adanya hari kebangkitan. ${ }^{49}$

Berikut skema medan semantik kata matar dalam Alquran:

${ }^{48}$ Al-Qurțubī, Al-jāmi'li Abkàm al-Qur'ān, vol. 9 (Baerut: Muassasah al-Risālah, 2006), 495.Al-Qurțubī, Al-Jāmi'li Abkēm al-Qur'àn, vol. 19 (Baerut: Muassasah al-Risālah, 2006), 212.

${ }^{49}$ Al-Alūsi, Rūhal-Mà ānì, vol. 19 (Baerut: Dār Iḥyā al-Turātats al-`Arabī, n.d.), 22. 


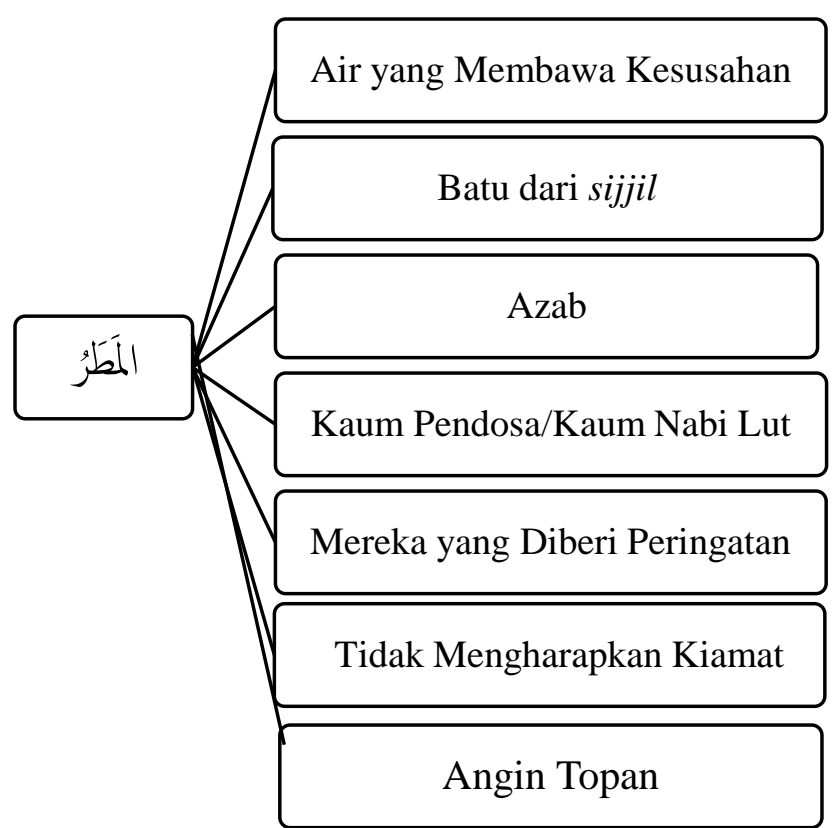

Gambar 4: Skema medan semantik kata matar dalam Alquran

Konsep Alquran tentang Mațar

Sesuai dengan makna dasarnya, kata mațar dalam Alquran sangat erat kaitannya dengan sesuatu yang turun dari langit.Hanya jika pada masa Jahiliyyah kata matar memiliki makna yang positif, maka kata matar dalam Alquran memiliki makna yang negatif.

Dalam sya'ir-sya'ir Arab Jabiliyyah kata matar berrelasi dengan hujan, awan, air, bunga, buah-buahan dan oase. Sedangkan dalam Alquran kata kata mațar berrelasi dengan tiga hal yakni: azab, hujan air yang membawa kemadharatan dan hujan batu yang mematikan. Hujan batu itu menimpa kaum pendosa, yang menolak peringatan dari Allah Swt. dan bersikeras tidak beriman pada hari kebangkitan, bahkan mereka tidak segan-segan menantang agar azab Allah datang selekas mungkin.

Temuan ini menjadi bukti telah terjadinya pergeseran makna kata matar. Makna kata matarpada masa Jahiliyyah yang semula positif berubah menjadi negatif. Berdasarkan medan maknanya, konsep matar dalam Alquran dipastikan $100 \%$ berkonotasi negatif. Muatan positif yang semula diemban oleh kata itu di masa Jahiliyyah telah digantikan oleh kata yang lain dalam Alquran yaitu kata ماء(ma'u) dan (الغيث) (al-ghaits). 


\section{Kesimpulan}

Setelah melakukan pemaparan di atas, penelitian kami menunjukkan terdapat empat kelemahan dalam model analisis semantik Alquran yang ditawarkan oleh Izutsu yakni terkait sifat, legitimasi, referensi dan kegunaan hasil penelitiannya. Kelemahan tersebut dapat direduksi dengan menggabungkan analisis semantik ke dalam metode tafsir maudhu'i. Di satu sisi, semantik Alquran akan memperoleh legitimasi dalam tradisi Islam, di sisi lain tafsir maudbu'i akan memperoleh alat analisis yang tajam sebagai balasannya. Tentu saja penggabungan itu akan mengakibatkan perubahan sifat, referensi dan kegunaan semantik Alquran. Namun justu inilah unsur baru yang hendak ditawarkan oleh analisis semantik Alquran model Ensiklopedik. Hasil eksperimen dari penerapan analisis model ini terhadap beberapa tema Alquran telah menunjukkan hasil yang memuaskan, termasuk untuk tema yang sangat sederhana seperti kata matar.

Dalam pengembangan model analisis semantik yang kami tawarkan, terdapat enam langkah dalam melakukan analisis di antaranya adalah menentukan kata, mengumpulkan ayat-ayat, meneliti makna dasar dan makna relasional, menentukan makna dasar dan makna relasional, membuat medan makna, dan menuliskan konsep. Hasil dari aplikasi keenam tahap di atas atas kata matar dalam Alquran yang biasa diartikan sebagai hujan menunjukkan hasil bahwa terjadi pergeseran makna kata tersebut pada masa Jabiliyyahdan masa Alquran. Kata matar memiliki makna yang positif pada masa Jabiliyyah, sementar kata matar dalam Alquran memiliki makna yang negatif.

\section{Ucapan Terima Kasih}

Penulis menyampaikan ucapan terima kasih yang sebesar-besarnya kepada Lembaga Penelitian dan Pengabdian Masyarakat (LP2M) Universitas Islam Negeri (UIN) Sunan Gunung Djati Bandung yang telah memberikan dana penelitian sehingga tulisan ini bisa terwujud. Ucapan terima kasih juga penulis sampaikan kepada seluruh mahasiswa Jurusan Ilmu Alquran dan Tafsir (IAT) Fakultas Ushuluddin yang telah ikut serta membantu penelitian ini.

\section{Bibliografi}

Abd al-Hayy al-Farmawi.Al-Bidayah Fi al-Tafsir al-Maudbu'i Dirasah Manhajizah Mawdhu'iyah. Kairo: Mathba'ah al-Hadlarah al-Arabiyah, 1997.

Abdul Kabir HussainSolihu. "Semantics of the Qur'anic Weltanschauung: A Critical Analysis of Toshihiko Izutsu's Works." American Journal of Islamic Social Sciences Vol. 26, No. 4 (2009). 
Ahmad Ibn Fāris. Mu'jam Maqāyìs Lughah. Beirut: Dār al-Fikr, n.d.

Aisyah, Aisyah. "Signifikansi Tafsir Maudhu'i dalam Perkembangan Penafsiran Al-Qur'an" 1, no. 1 (February 20, 2019). http://journal.uinalauddin.ac.id/index.php/tafsere/article/view/7449.

Al-Alūsi.Rūhhal-Ma ānì.Vol. 19. Baerut: Dār Iḥyā al-Turātats al-`Arabī, n.d.

Albayrak. "The Reception of Toshihiko Izutsu's Quranic Studies in the Muslim World: With Special Reference to Turkish Quranic Scholarship," n.d.

Al-Marāgī, Aḥmad Musțāfā.Tafsìr Al-Marāgì. Vol. 8. Mesir: Syirkah Maktabah wa Maṭba’ah Muṣtafā al-bBābī al-Ḥalabī wa Awlaāduh, 1946.

Al-Qurțubī.Al-Jämi'li Abkām al-Qur'ān.Vol. 9. Baerut: Muassasah al-Risālah, 2006.

Al-Jāmili Abkām al-Qur'ān.Vol. 19. Baerut: Muassasah al-Risālah, 2006.

Al-Raghib al-Ishfahaniy.Mu'jam Mufradat Fì Gharib Alqurān.Maktabah Nazar Musthafa al-Bazz, n.d.

Al-Ṭabarī.Jämi' al-Bayān 'an Ta wàl Àyì al-Qur 'än. Vol. 5. Baerut: Mu'assasah alRisālah, 1994.

Antarah bin Syadad. Diwan Antarah Bin Sadad.Edited by Amin Said. Kairo: alMaktabah al-Tijariyah al-Kubra, n.d.

Bacon, Lord. Novum Organum. New York: P.F. Collier and Son, MCMI, n.d.

Baidan, Nashruddin. Rekonstruksi Ilmu Tafsir. Jakarta: Dana Bhakti Prima Yasa, 2000.

Benjamin L. Whorf. Language, Thought and Reality: Selected Writing of Benjamin L. Whorf. Edited by J.B. Carroll. Cambridge: M.I.T. Press, 1956.

Bréal, Michel. Semantic Studies in The Science of Meaning. Translated by Nina Cust. New York: Henry Holt \& Co, 1900.

Darmesteter, Arsene. The Live of The Words as The Symbols Of Ideas. London: Kegan Paul, Trench \& CO.-Paternoster Square, 1886.

Dāud.Mujam Al-Furuq Diläìyah Fì Alqurān al-Karìm, n.d.

Eisa al-Akub. "Izutsu's Study of the Quran from an Arab Perspektif." Jurnal of Quranic Studies V. 14 No.1 (2012).

Fazlur Rahman. Islam and Modernity, Transformation of an Intellectual Tradition. Chicago: University of Chicago Press, 1984.

Ferdinand de Saussure. Course in GeneralLinguistics.Translated by Wade Baskin. London: Owen, 1960. 
F.H. George. Semantic. London: The English University Press, 1964.

Foucault, Michel. Archeology of Knowledge and The Discourse on Language. New York: Pantheon Books, 1971.

Ibn 'Ashūr.Tafsìr Al-Tahrìr Wa al-Tanwìr. Vol. v.12.Tunis al-Dār al-Tūnisiyah li al-Nasyr, 1984.

Ibn Katsir. Tafsiìr Al-Qur'ān al-'Ażim. Riyadh. Vol. v.3.Dār Ṭoyyibah li al-Nasyr wa al-Tawzî, 1999.

Ibn Mandzur. Lisān Al-A'rab. Vol. v. 5. Baerut: Dār al-Shādir, 2010.

Ismail Albayrak. “The Reception of Toshihiko Izutsu's Quranic Studies in the Muslim World: With Special Reference to Turkish Qur`anic Scholarship." Jurnal of Quranic Studies V. 14 No.1 (2012).

J.Trier. Der Deutche Wortschatz Im Simnbezirk Des Verstandes.Heidelberg, 1931.

Karim Ouda. Quran Analysis: A Semantic Search and Intelligence System for the Quran. UK: Leeds University, 2015.

Lilik Ummi Kaltsum. "Alquran Dan Epistemologi Pengetahuan: Makna Semantik Kata Ra'a, Nažar Dan Bașar Dalam Alquran.” Wawasan: Jurnal Ilmiah Agama Dan Sosial Budaya Vol. 3, No. 1 (2018).

M. Nur Kholis Setiawan. Al-Qur'an Kitab Sastra Terbesar. Yogyakarta: eLSAQ Press, 2005.

M. Quraish Shihab. Tafsir Al-Misbab: Pesan,Kesan Dan Keserasian Alquran. Vol. v.2. Jakarta: Lentera Hati, 2002.

"M. Tulus Yamani, Memahami Al-Qur'an Dengan Metode Tafsir Maudhu'I, JPAI, 1 (2)," 2015.

Muhammad AbdulBaqi. Mu'jam Mufahras LiAlfaz, Alquran al-Karim. Kairo: Dar al-Hadis, 2007.

Muhammad Muhammad Dāud. Mujam Al-Furuq Diläinyah Fì Alqurān al-Karìm. Kairo: Dār al-Gharīb, 2008.

Muzaqqi. "Semantic Approaches In Islamic Studies: The Review of Toshihiko Izutsu's Thought." Pedagogik: Jurnal Pendidikan Vol. 4, No. 1 (2016): 4553.

Nafiul Lubabdan Muhammad Dimyati. "Urgensi Pendekatan Semantik Dalam Tafsir (Studi Pemikiran Toshihiko Izutsu)." Hermeneutik: Jurnal Ilmu AlQur'an Dan Tafsir Vol. 11, No. 1 (2017). 
Partin. "Semantics of the Qur`an: A Consideration of Izutsu's Studies."History of Religions" V.9 No.4 (1970).

Radiana, Aan. "Kontribusi Analisis Semantik Bagi Metode Tafsir Tematik." Skripsi, Institut Agama Islam Negeri Sunan Gunung Djati Bandung, 1994.

Rahman, Miftahur. "Kata Al-Ikhlash Dalam Alquran: Kajian Semantik." Al Quds: Jurnal Ilmu Alquran Dan Hadis Vol. 2, No. 2 (2018).

Saussure Ferdinand de.Saussure's Third Course of Lectures on General Linguistics (1910-1911). Pergamon Press, 1993.

Shalah al-Din Al-Zaral. "Applied Semantics and the Qur'an: Izutsu's Methodology as a Case Study." Jurnal of Quranic Studies V. 14 No.1 (2012).

Stephen Ullmann. Semantic an Introduction to the Science of Meaning. Oxford: Basil Backwell, 1972.

Stern, Gustav. Meaning and Change of Meaning with Special Reference to the English Language. Gothenburg: Goteborg Hogskolas Arsskrift XXXVIII, 1931.

Toshihiko Izutsu. Ethico-Religious Concepts in Qur an. Montreal-London: McGillQueen's University Press, 2002.

—. Ethico-Religious Concepts in TheQuran. London-Montreal: McGillQueen's University Press, 2002.

- God and Man in the Qur'an Semantics of the Qur anic Weltanschaunng. Petaling Jaya: Islamic Book Trust, 2008.

Ullmann, Stephen. Semantic an Introduction to the Science of Meaning. Oxford: Basil Backwell, 1972.

Zulfikar. "Makna Ūlū Al-Albāb Dalam Al-Qur'an: Analisis Semantik Toshihiko Izutsu." Jurnal Theologia Vol 29, No 1 (2018). 